\title{
The Effects of Brand Credibility on Customer's WOM Communication: The Moderator Role of Brand Commitment A Conceptual Paper
}

\author{
Methaq Ahmed Sallam ${ }^{1}$ \\ ${ }^{1}$ College of Administrative Sciences, Najran University, Saudi Arabia \\ Correspondence: Methaq Ahmed Sallam, College of Administrative Sciences, Najran University, P O Box 1988, \\ 11001 Najran, Saudi Arabia. Tel: 966-55-6573-2028. E-mail: methaq68@hotmail.com
}

Received: June 15, 2014 Accepted: July 2, 2014 Online Published: September 28, 2014

doi:10.5539/ijms.v6n5p112 URL: http://dx.doi.org/10.5539/ijms.v6n5p112

\begin{abstract}
The use of brand credibility by companies continues to be a popular method to support the brand commitment, and to encourage the customer to own more satisfaction and positive word of mouth communication about the brand. When the customers focus on the positive aspects of a company, they usually express it by using the positive words of mouth communication, and which in turn is considered the goal of any company. The reason that lies behind using brand credibility is its direct and indirect strong impact that makes customers more positive toward the brand. This theoretical paper develops a conceptual framework that explains how brand credibility affects brand commitment, and brand commitment impacts on the dependent variable which is called word of mouth communication. Furthermore, this framework shows that brand credibility is the independent variable, brand commitment is the mediating variable and the word of mouth communication is the dependent variable of this study.
\end{abstract}

Keywords: Brand Credibility, Brand Commitment, WOM Communication

\section{Introduction}

Customers often remember the most successful companies in different ways, for example, during the procurement process or advising others, and those companies focused on the quality of the provided product and service.

Nowadays, in order to define a brand, give its emphasis on identity, which is an important invisible element, but has originality and roots. One of the favorite areas of brand management is creating a sense in consumers' minds through the identity for the brands (Kazemi et al., 2013).

According to Thomas et al. (2012), the most important asset of a company is the brand they own. For customers, a brand can simplify the choice process, promise quality, reduce risk (Keller \& Lehmann, 2006) and also motivate repeated buying (Aaker, 1996; Keller, 2001).

A strong brand is a competitive advantage, a barrier for entry in some markets, easier acceptance among distributors and consumers etc. for the organization it owns (Farquhar, 1989).

Many authors consider that the credibility of the brand is a major cause of customer satisfaction and loyalty, which creates its turn to talk with people in a positive way about the product or the service, which in turn gives the company a lot of profits and competitive strength. Literature of this study, tries to give more details about this point, which are as follows:

The management of customer is a top priority of executives in service industries such as retail banking and telecommunications. It is accepted wisdom in marketing that new customer acquisition is a far more costly undertaking than establishing a broader and deeper relationship with existing customers (Sweeney \& Swait, 2008). The high speed of exchange and communication leads to the creation of a very competitive market for companies which are working not only in the international scale, but also in the local one (Ghorban \& Tahernejad, 2012). The survival path in this competitive market is trying to attract more customers and retain them (Sweeney \& Swait, 2008). Therefore, the more a company attracts customers, the more it generates profit and value for company.

Ghorban \& Tahernejad (2012) believed that attracting more customers is not a key factor to have a successful firm. 
Their notion was that in the new economics, managers have to focus more on the frontline staff and the technology, because they found that there is a way to make profit in the economy. Heskett et al., (1994) had drawn a chain, this chain included a linkage between firm profitability, customer loyalty and pleasure, and yield of employees of the firms, they mentioned that value and revenue are outcomes of customer loyalty. Besides, satisfied customer can create loyal customer and satisfaction is influenced by the quality of offered products and services. Heskett et al. (1994) mentioned that retaining customer create more profit and value that attract more new customers.

That researchers have focused on importance of customer retention of churn. Their studies have shown that preventing customer churn is a key competitive issue in financial and telecommunication industry (Teradata, 2004). Besides, these kinds of service providers must concentrate their efforts on customer retention. Evans (2002) examined churn or retention on telecommunication industry and financial sector. Ghorban et al. (2012) explored the retention on internet service delivers. There are few factors that can influence the retention of customers, for example, offering product and services with vast names and brand targets today's customers.

Any competitive firm in the market, can maintain customers through its brand credibility and the commitment of the brand, which is leads the customers to talk positively about the company and brand, by different way, Talk positively of customers does not stop about the credibility of the brand, 'As long as the brand continues and keep its credibility and commitment to its customers. Brand credibility is considered wealth for any company, it can be used as strong points in the competition market.

This study tries to explore the effect of brand credibility on customer's word of mouth communication when brand commitment is mediating relationship between independent variable and independent variable.

\section{Problem Statement}

Although many studies have been conducted on this issue, but there are still gaps which are needed to be filled in the literature. Previous studies which are related to this area of study only focused on certain aspects of WOM communication process, and the variables used in thoes studies were segmented in nature. In other words, the model proposed in this study is an integrative model, and came from three separate models found in the related area of literature, For example, study of (Thomas et al., 2012) explored the relationship between brand credibility and brand commitment, study of (Malik et al., 2014) illustrated the effect of brand credibility and the word of mouth, and study of (Kazemi et al., 2013) explored the relationship between brand commitment and word of mouth communication. This means, that three main models of this study were segmented in three different studies, and each one was tackled alone. This study tries to integrate them in one conceptual framework, and this is the contribution of this study.

\section{Literature Review}

For businesses that are offering products and services to the public, the customers are considered as one of the most important factors to be attended very carefully, since their wants and desires would have significant impacts on the way the businesses are run. Brand credibility, brand commitment and the word of mouth as a consequence of satisfaction and loyalty of customers are the main issues in this study which have a strong relation with the retention of customer as a key success factor in today's business world. These issues are discussed in details to allay concepts of these concerns here.

\subsection{Brand Credibility}

According to Ohanian (1990) source credibility is all about creating positive characteristics from sender that manipulates a receiver to accept the message sent by sender. This can also be regarded as brand credibility is validity of communication assertions or the believability of intentions of an article at a certain time. This sender can be person, cartoon, corporation and/or brand (Wang \& Yang, 2010). Previous researches explored that the source credibility is a composite of three elements 1) trustworthiness 2) expertise 3) attractiveness (Erdem et al., 2004). A brief description as described by (Erdem et al., 2004) of these three elements is given as under:

1). Trustworthiness: To what extent a brand is considered a reliable source of information.

2). Expertise: The extent to which a specific brand has good knowledge and skills.

3). Attractiveness: To what extent a brand is evaluated in term of personality determinants.

Malik et al. (2014) informed that brand credibility involves the extent to which a consumer perceives a brand a reliable source of information (trustworthiness), skills (expertise) and matches it with personality characteristics (attractiveness). Gilaninia et al. (2012) Mentioned that brand credibility is believability of product status information, which is embedded in following brand, depending on consumers' perceptions of whether the brand has the ability and willingness to continuously deliver what has been promised. It has been well known that brand 
credibility consists of two main components: trustworthiness and expertise.

Erdem and Swait (1998) defined brand credibility as the believability of product position information contained in a brand, which entails consistently delivering what is promised, and they informed that brand credibility has two dimensions, trustworthiness and expertise. Trustworthiness means that it is believable that a brand will deliver what it has promised, and expertise implies that the brand is believed capable of delivering the promises.

Sheeraz et al., (2012) mentioned that brand credibility is originated from source credibility literature. According to Ohanion (1990) source credibility is positive characteristics of a sender that influence receiver's message acceptance, or validity of communication assertions (Enrique, Rafael, \& Isabel, 2009), or believability of intentions of entity at particular time (Herbig \& Milewicz, 1995). This sender, communicator or entity can be person, cartoon, corporation and/or brand (Wang \& Yang, 2010). Previous research described that source credibility comprised of trustworthiness, expertise and attractiveness (Hovland, Janis, \& Kelly, 1953; Sternthal \& Craig, 2002; Keller \& Aaker, 1997). So brand credibility refers to believability in characteristics of brand product information. It has three elements trustworthiness, expertise and attractiveness. Baek et al., (2011) mentioned that, the notion of brand credibility was inspired by Erdem and Swait (1998), who examined consumer-based brand equity based on signaling theory. As briefly mentioned before, brand credibility is the believability of the product position information embedded in a brand depending on consumers' perceptions of whether the brand has the ability and willingness to continuously deliver what has been promised (Erdem and Swait, 2004). Brand credibility is thought to consist of two main components: trustworthiness and expertise (Erdem and Swait, 1998; 2004, Erdem et al., 2002; 2006). Trustworthiness refers to the willingness of firms to deliver what they have promised. Expertise refers to the ability of firms to deliver what they have promised. Since the trustworthiness and expertise of a brand are based on the cumulative impact of all previous marketing strategies and actions taken by a brand (Erdem and Swait, 1998), it is not surprising that brand credibility reflects the consistency of the marketing mix through brand investments such as advertising.

Consumers form brand loyalty based on several reasons, including satisfaction, risk reduction, or trust. Among these reasons, evidence about the importance of trust in loyal relationships is paramount (Kim et al., 2008). Morgan and Hunt (1994) indicated that trust is a strong predictor of relationship commitment. Many other studies have shown that trust is at the core of successful relationships (e.g., Berry 1995). Morgan and Hunt (1994) defined trust as the perception of "confidence in the partner's reliability and integrity" (1994, p. 23). Moorman, Zaltman, and Deshpande (1992) argue that trustworthiness results from expertise, reliability, and intentionality. Subsequently, Gwinner, Gremler, and Bitner (1998) found the psychological benefit of trust to be more important than special treatments in consumer relationships with service firms. Ghorban \& Tahernejad (2012) cited from Kotler and Keller (2008) that they described the brand as the name, term, sign, symbol, design, or combination of them, intended to identify the goods or services of one seller or group of sellers and to differentiate them from those of competitors. Ghorban \& Tahernejad (2012) mentioned that customers and users evaluate identical products and services based on their brands, one way to reach information about brands is past experiences by customers, customers compare different brands to selected best ones according to their needs and requirements.

In term of credibility, which is the central point here, Herbig and Milewicz (1995) pointed that credibility is relying on a company commitments and promises in a specific time period, and they defined some points for credibility, time sensitive and firm's intentions are two important characteristics of credibility which firm must consider, credibility will be concluded in customers mind when the behavior of firm in future is predictable by its present actions.

Considerable prior research (Hovland et al., 1953) reveals that source credibility consists of trustworthiness, expertise, and attractiveness/likeableness. Thus, brand credibility refers to the believability of the product information embodied in a brand and is suggested to contain three elements, i.e., trustworthiness, expertise, and attractiveness/ likeableness (Hovland et al., 1953). Hence, brand credibility requires consumers to perceive that the brand is willing (trustworthiness), has the ability (i.e., expertise), and is dedicated (i.e., attractiveness/ likeableness) to consistently deliver what has been promised (Erdem \& Swait, 2004). Herbig and Milewicz (1995) propose a historical perspective about brand credibility to the effect that past and present marketing activities can influence current and future brand credibility. Trustworthiness, expertise, and attractiveness of a brand therefore reflect the cumulative effects of past and current marketing investments. Erdem and Swait's (1998), Erdem et al. (2002) considered two main aspects for brand credibility which are expertise and trustworthiness. Erdem et al. (2002) recommended Erdem and Swait (1998) study where they described trustworthy as the purpose of a credible brand, and expertise as capacity to convey brand commitments. Erdem et al. (2002) indicated that there are negative relationships among brand credibility of a product or service and customer's supposed risks; besides, quality is another subject that is influenced by credibility. As a whole, Erdem et al. (2002) highlighted brand credibility to 
include two main important factors which lead to raise customers' expectation: swelling perceived quality and declining perceived risks. Alcaniz et al. (2009) described brand credibility dimensions as the honesty and helpfulness of brands and company's sufficient ability and knowledge as trustworthiness and expertise. A few studies have investigated the effect of brand credibility, for example, Erdem, Swait, and Louviere (2002) suggested that brand credibility may act as a moderating variable in the impact of product price on consumer utility. In this study brand credibility will be used as independent variable. Therefore, the next part aims to find, explore and justify these consequences based on the existing literatures.

\subsection{Brand Commitment}

The commitment refers to the sustainable tendency toward continuing the buying relationship with a company. The consumers tend to improve and maintain the emotional associations with which brand that results in their warm and enjoyable feeling. On the other hand, the consumers will have more powerful emotional belonging to the brand. The commitment can be divided into two components including emotional commitment and continuity (Kazemi et al., 2013). There is a significant relationship between emotional commitment and the brand name. This refers to the powerful personal feeling and emotional business commitment based on the identification and shared brand values. The emotional commitment refers to the deep belonging toward brand. In the continuity commitment, the customer will change the brand as he/she has week feeling toward it (Aysel, 2012). Commitment was defined as a psychological attachment to the brand and also has a close relationship with behavioral loyalty. Commitment leads that the customer express his/her defensive motivations and then these will result in high levels of commitment. There are several consumer behavior studies that examine the role of commitment in the adjustment of advertisement effects. The first effect of the commitment is that the behavior and cognition are resistant to change. The customer who define the concepts of commitment and attitude in the frame of behavioral and attitude commitment, they will have more resistant to change (Kishore et al., 2008). Kemp et al. (2011) mentioned that brand commitment is an enduring desire to maintain a valued relationship (Moorman et al., 1992). It refers to the economic, emotional and psychological attachments that a consumer may have toward a brand (Evanschitzky et al., 2006).

Kim et al. (2008) mentioned, Consistent with Fishbein and Ajzen (1975), we view behavioral intention as the most predictable of behaviors, and thus propose a direct antecedent of loyalty behavior. This intentional brand loyalty construct is "brand commitment," which we view as behavioral intention held with affective and cognitive conviction. In psychology, the concept of commitment is regarded as having intentional aspects, as evidenced by Kiesler et al. (1971) definition of commitment: "the pledging or binding of an individual to behavioral acts" (1971, p. 30). Contrary to many studies that viewed brand commitment as a direct indicator (i.e., a scale item) of brand loyalty, we regard it as a construct anteceding brand loyalty behavior.

\subsection{Word of Mouth Communication}

Money (2004) mentioned that consumers search for information prior to making a purchase in order to reduce perceived risk. One such source of information is word of mouth (WOM). Marketing researchers have shown that WOM communication has an impact on consumer attitudes, consumer risk taking, short-term and long-term product judgments and purchase decisions and choice behavior.

Kemp (2011) informed that decades of consumer research has shown Word-of-Mouth Communication (WOMC) to be a powerful influence on consumers' brand attitudes, judgments, and purchase intentions. It is generally more influential than advertising due to its higher credibility and more interactive nature. Accordingly, marketers are highly motivated to understand and exploit this powerful information source. Walker et al. (2001) mentioned that, Word-of-Mouth Communication can be generated in many different ways. For example, a consumer may actively seek out product advice from an acquaintance they perceive to be an expert (solicited WOMC). He/she may overhear two unknown consumers discussing a product, store, or service, or he may be given unsolicited (or even unwanted) product information from someone. He/she may read product reviews on a website from complete strangers. It is this organic nature of WOMC that makes it powerful, but also makes it a challenging topic to study. It is clear that these different processes may produce WOMC that is highly variant in its perceived information value and its influence on the consumer.

Kazemi et al. (2013) mentioned that word of mouth communications refer to the extent in which a customer informs his/her friends, coworkers, and relative about product or services that satisfies his/her needs. With regard to the relationship between customer satisfaction and word of mouth communications, some authors pointed out that the form and type of this relationship can be different in every level of customer satisfaction. Hart et al. (2013) indicated that unsatisfied customers transfer their bad experiences to 11 potential customers. They also pointed out that the satisfied customers transfer their successful experiences to 6 ones. Additionally, the Fortune indicates that 
the results of different studies showed that the customers offer their positive experiences for 8 ones. One of the interpretations of this fact can be described by theory of asymmetric effects of positive and negative events. It can be claimed that the positive events create more powerful responses than negative ones in the especial circumstances. Based on theory of Tailor (1991), another reason of this is that the negative feelings and emotions are related to the act, but positive ones are related to the emotions and senses. Generally, it is more important for people that react the negative environment more than positive one. Also it can be indicated that most people have tendency to interpret the positive affairs more than negative one. Therefore, it can be concluded that the satisfied customers transfer their positive experiences to others more than unsatisfied ones Walker et al. (2001).

\subsection{The Relationship between Brand Credibility and Brand Commitment}

In terms of the relationship between brand credibility and brand commitment, it is noted, that literature review of this area of relationship in previous studies especially who used these types of variables (brand credibility and brand commitment) relationship were little and rare, and the researcher just found one study related to the main variables that used, for example, Thomas et al. (2012) found that credibility of brand has significant and positive effect on brand commitment. Also he found another study related to the general idea of brand credibility and brand commitment, but used different variables names, for example, study of John et al. (2012), they found credibility of leadership had significantly effects on his/her commitment. Another study of Kemp et al. (2011), found that brand credibility had positive effect on brand commitment through the mediating variable which is called purchase intention.

\subsection{The Relationship between Brand Commitment and WOM Communication}

In terms of the relationship between brand commitment and WOM communication, it is illustrated that previous studies in this type of variables relationship were rare, and the researcher just found one study related to the main variables that used, for example, results study of (Kazemi et al., 2013) explored that brand commitment influences word of mouth communications significantly, and it was the only one have taken the same variables. The researcher also found another study related to general idea of commitment and word of mouth, but still little far from the main variables of this study, for example, in the study of Walker et al. (2001) they referred in their study that there is a significant effect on the relationship between affective commitment and word of mouth activity, also they mentioned that there is a significant effect on the relationship between affective commitment and word of mouth praise.

\section{The Proposed Conceptual Framework}

The conceptual framework below is proposed to ensure that brand credibility effects on variable of brand commitment (Thomas et al., 2012) and a variable of word of mouth communication (Malik et al., 2014). Brand commitment impacts on WOM communication (Kazemi et al., 2013), when the brand commitment is the mediating between brand credibility and word of mouth communication.

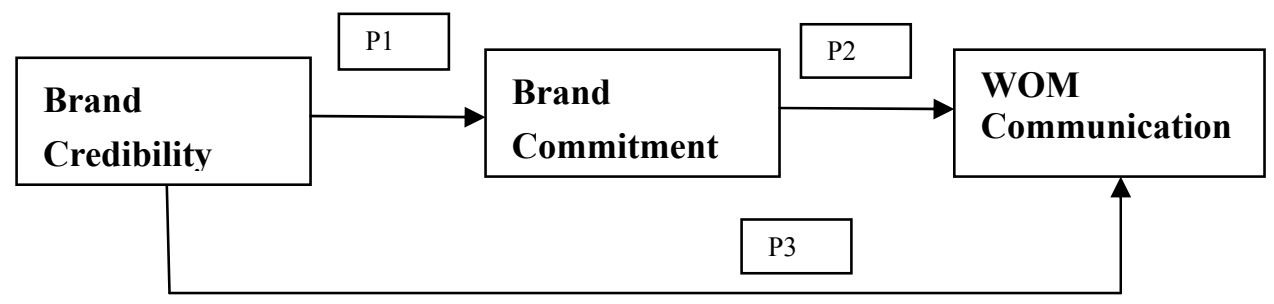

Figure 1. Conceptual framework of the study

\section{Conclusion}

This study aims to determine a conceptual framework, create a positive word of mouth communication by building brand credibility and to enhance the role of brand commitment. In addition, the study tries to illustrate the mediating role of brand commitment between brand credibility and word of mouth communication. If the study were applied in practice in the future by one of the researchers, the results will inform the company mangers how to use brand credibility well in the long term to improve the concept of brand commitment and to make customers create gorgeous and positive words about the brand. In addition, the study will give the researchers idea about the mediating role of brand commitment between brand credibility and consumer's WOM communication whether partial or full mediating. 


\section{References}

Aaker, D. A. (1996). Measuring brand equity across products and markets. California Management Review, 38(3), 102-120.

Alcañiz, E. B., Pérez, R. C., \& García, L. S. (2009). Brand credibility in cause-related marketing: the moderating role of consumer values. Journal of Product \& Brand Management, 18(6), 437-447. http://dx.doi.org/10.1108/10610420910989758

Baek, T. H., \& King, K. W. (2011). Exploring the consequences of brand credibility in services. Journal of Services Marketing, 25(4), 260-272.

Berry, L. L. (1995). Relationship Marketing of Services: Growing Interest, Emerging Perspectives. Journal of the Academy of Marketing Science, 23(Fall), 236-245.

Ercis, A. (2012). The effect of brand satisfaction, trust and brand commitment on Loyalty and repurchase intentions. Journal of Procedia - Social and Behavioral Sciences, 58, 1395-1404.

Erdem, T., \& Swait, J. (1998). Brand equity as a signaling phenomenon. Journal of consumer Psychology, 7(2), 131-157.

Erdem, T., \& Swait, J. (1998). Brand Equity as a signalling phenomenon. Journal of Consumer Psychology, 7(April), 131-157.

Erdem, T., \& Swait, J. (2004). Brand credibility, brand consideration, and choice. Journal of Consumer Research, 31(1), 191-198.

Erdem, T., Swait, J., \& Louviere, J. (2002). The impact of brand credibility on consumer price sensitivity. $\begin{array}{lllll}\text { International Journal of Research in } & \text { Marketing, } & 19(1), & 1-19 .\end{array}$ http://dx.doi.org/10.1016/S0167-8116(01)00048-9

Evanschitzky, H., Iyer, G. R., Plassmann, H., Niessing, J., \& Meffert, H. (2006). The relative strength of affective commitment in securing loyalty in service relationships. Journal of Business Research, 59(12), 1207-1213.

Farquhar, P. H. (1989). Managing brand equity. Marketing Research, 1(September), 24-33.

Fishbein \& Ajzen, I. (1975). Belief, Attitude, Intention, and Behavior: An Introduction to Theory and Research. Boston: Addison-Wesley.

Ghorban, S. Z., \& Tahernejad, H. (2012). A Study on Effect of Brand Credibility on Word of Mouth: With Reference to Internet Service Providers in Malaysia. International Journal of Marketing Studies, 4(1).

Gilaninia, S., Ganjinia, H., Moridi, A., \& Rahimi, M. (2012). The Differential Roles of Brand Credibility and Brand Prestige in the Customers' Purchase Intention. Kuwait Chapter of Arabian Journal of Business and Management Review, 2(4).

Gwinner, K. P., Dwayne, D. G., \& Bitner, M. J. (1998). Relational Benefits in Service Industries: The Customer's Perspective. Journal of the Academy of Marketing Science, 26(Spring), 101-114.

Hart, K. (2013). Word of mouth Introducing Britain to fresh cinnamon: Rupert Beeley and his wife, Charlotta, are on a mission to share the joys of fresh cinnamon. Telegraph Magazine, 63.

Herbig, P., \& Milewicz, J. (1995). The Relationship Of Reputation And Credibility To Brand Success. Journal of Consumer Marketing, 14(Winter), 5-10. http://dx.doi.org/10.1108/07363769510795697

Herbig, P., \& Milewicz, J. (1995). The relationship of reputattion and credibility to brand success. Journal of Consumer Marketing, 615-39.

Heskett, J. L., Jones, T. O., Loveman, G. W., \& Sasser, W. E. J. (1994). Putting the service-profit chain to work. Harvard Business Review, March-April, 164-174.

Hovland, C. I., Janis, I. K., \& Kelley, H. H. (1953). Communication and Persuasion. New Haven, CT: Yale University.

Hovland, C., Janis, I., \& Kelly, H. (1953). Communications and Persuation. New Haven: CT: Yale Uinversity Press.

John, E., \& Richard, G. (2012). Credibility, Commitment and Dialogue: Cornerstones of Leadership. Corrections Today; Feb/Mar 2012; 74, 1; ProQuest Central.

Kazemi, A., \& Javad, P. (2013). Impact of Brand Identity on Customer Loyalty and Word of Mouth Communications, Considering Mediating Role of Customer atisfaction and Brand Commitment. (Case Study: 
Customers of Mellat Bank in Kermanshah). International Journal of Academic Research in Economics and Management Sciences, 2(4).

Keller, K. L. (2001). Building customer based brand equity: a blue print for creating strong brands. Marketing Science Institute, Working Paper 01-107.

Keller, K. L., \& Donald, R. L. (2006). Brands and branding: Research findings and future priorities. Marketing Science, 25(6), 740-759.

Keller, K., \& Aaker, D. (1997). Managing the corporate brand: The effects of corporate marketing activity in consumer evaluation and brand extensions. Marketing Science Institute Working Paper, 97-106, 1-66.

Kemp, E., \& Bui, M. (2011). Healthy brands: establishing brand credibility, commitment and connection among consumers. Journal of Consumer Marketing, 28(6), 429-437.

Kiesler, C. A. (1971). The Psychology of Commitment: Experiments Linking Behavior to Belief. New York: Academic Press.

Kim, J., Swait, J., \& Morris, D. J. (2008). Antecedant of brand loyalty. The Journal of Advertising, 37(2), 99-117.

Malik, M. S., \& Ahmad, N. (2014). Impact of Brand Credibility on Consumer Loyalty A Case Study of Fast Food Industry in DG Khan, Pakistan. Arabian Journal of Business and Management Review, 3(6).

Mathew, V., Thomas, S., \& Injodey, I. J. (2012). Direct and Indirect Effect of Brand Credibility, Brand Commitment and Loyalty Intention on Brand Equity. Economic Review-Journal of Economics and Business, $X(2)$.

Money, R. B. (2004). Word-of-mouth promotion and switching behavior in Japanese and American business-to-business service clients. Journal of Business Research, 57, 297-305.

Moorman, C., Zaltman, G., \& Deshpande, R. (1992). Relationships between Providers and Users of Market Research: The Dynamics of Trust within and Between Organizations. Journal of Marketing, 58(July), 20-38.

Ohanian, R. (1990). Construction and validation of a scale to measure celebrity endorsers' perceived expertise, trustworthiness, and attractiveness. Journal of Advertising, 19(3), 39-52.

Pillai, K. G., \& Goldsmith, R. E. (2008). How brand attributetypicality and consumer commitment moderate the influence of comparative advertising. Journal of Business Research, 61, 933-941.

Sheeraz, M., Iqbal, N., \& Ahmed, N. (2012). Impact of Brand Credibility and Consumer Values on Consumer Purchase Intentions in Pakistan. International Journal of Academic Research in Business and Social Sciences, 2(8).

Sternthal, B., \& Craig, C. (2002). Consumer behavior: An information processing perspective. Englewood Cliffs, NJ: Prentice Hall.

Sung, Y. J., \& Campbell, W. K. (2009). Brand Commitment in Consumer-Brand Relationships: An Investment Model Approach. Journal of Brand Management, 17(2), 97-113.

Teradata. (2004). Bank execs cite customer churn as key competitive issue in 2004. Retrieved from http://www.ncr.com/media_information/2004/feb/ pr022404.htm

Walker, H., \& Jean, L. (2001). The Measurement of Word-of-Mouth Communication and an Investigation of Services Quality and Customer Commitment as Potential Antecedent. Journal of Service Research, 4.

Wang, X., \& Yang, Z. (2010). The effect of brand credibility on consumers' brand purchase intention in emerging economies: the moderating role of brand awareness and brand image. Journal of Global Marketing, 23(3), $177-188$.

\section{Copyrights}

Copyright for this article is retained by the author(s), with first publication rights granted to the journal.

This is an open-access article distributed under the terms and conditions of the Creative Commons Attribution license (http://creativecommons.org/licenses/by/3.0/). 